\title{
Public Speaking: Upaya Meningkatkan Kepercayaan Diri Santri dalam Berbicara Bahasa Inggris di Pesantren Al-Ghozali
}

\author{
Lida Holida Mahmud ${ }^{1}$, Mursyid Anwar'2, Yamin' ${ }^{3}$, Yunita $^{4}$ \\ Universitas Pamulang ${ }^{1,2,3,4}$ \\ Korespondensi: lidamahmud79@gmail.com ${ }^{1}$, dosen01428@unpam.ac.id ${ }^{2}$, \\ dosen01094@unpam.ac.id ${ }^{3}$, dosen02584@unpam.ac.id
}

\begin{abstract}
Based on observation, teachers at Pondok Pesantren Al-Ghozaly needed an approach for their students to be willing and confidence in speaking English. Everyone can speak, however not everyone is able to arrange words into sentences that are meaningful, pleasant to be hear and able to persuade interlocutor or audiences. Those obstacles cause unwillingness to speak in English for some students, particularly the students of Pesantren Alghozali. To deal with that challenge, Community Service (PkM) of Pamulang University in collaboration with Islamic Boarding School Al-Ghozali promoted Public Speaking that aims to enhance students'self confidence in speaking English in public. This PkM used Speech simulation as a sort of public speaking through learning video which was then applied in Pesantren Al-Ghozali with guidance from mentors, either lecturers who did PkM or English teachers of Al-Ghozali. The results showed that it was found that students were very enthusiastic to learn public speaking. Eventhough some of them looked shy, it did not dampen their enthusiasm to speak in public.
\end{abstract}

Keywords: community service, public speaking, speaking English, self confident, Islamic Boarding School Al-Ghozali

\begin{abstract}
Abstrak
Berdasarkan observasi, Pondok Pesantren Alghozali membutuhkan sebuah pendekatan bagi santrinya untuk mau dan percaya diri berbicara dalam bahasa Inggris. Untuk menjawab tantangan tersebut, PkM UNPAM bekerjasama dengan Pesantren mengusung kegiatan Public Speaking yang bertujuan untuk mendorong keperayaan diri santri dalam berbicara bahasa Inggris di depan umum. Semua orang dapat berbicara, tetapi tidak semua orang mampu meramu kata menjadi kalimat kalimat yang bermakna, enak didengar dan mampu mempengerahui lawan bicara atau pendengarnya, sehingga hal ini terkadang menjadi kendala bagi santri untuk tidak mau berbicara di depan umum, apalagi dalam Bahasa Inggris. PkM ini menggunakan metode simulasi public speaking dalam bentuk pidato pada video pembelajaran yang kemudian diaplikasikan di Pesantren Alghozali dengan pengarahan dan binaan dari mentor baik dari dosen yang melakukan PkM maupun pengajar Bahasa Inggris di pesantren tersebut. Dalam PkM tersebut, santri sangat antusias mempelajari Public Speaking serta terdorong untuk mau berbicara di depan umum. Meskipun masih ada santri yang terlihat malu-malu, tetapi kegiatan ini tidak menyurutkan antusias mereka untuk tampil berbicara di depan umum.
\end{abstract}

Kata kunci: PkM, public speaking, berbicara bahasa Inggris, percaya diri, Pondok Pesantren AlGhozali 


\section{A. Pendahuluan}

Proses globalisasi di setiap bidang, termasuk dalam keterampilan berbahasa Inggris, terus berkembang yang kemudian menggerus setiap orang yang tidak bisa beradaptasi dengannya. Arus pasar bebas dan kerjasama global yang tak terhindarkan menjadikan kemampuan berbahasa Inggris sebagai kemampuan yang mutlak harus dimiliki saat ini. Semua orang bebas mengakses informasi dari seluruh dunia, mengemukakan ide pendapat dan melakukan bisnis dengan siapa saja termasuk dengan negara lain. Poin utama pada pasar bebas ini bukan hanya bisa berbicara Bahasa Inggris saja, tetapi mampu berinteraksi dan mengkomunikasikan ide kepada individu lain maupun publik. Tentunya, kemampuan public speaking menjadi modal yang harus diperhitungkan masyarakat Indonesia dalam menghadapi persaingan yang semakin ketat pada era global ini. Girsang (2018, p8185) menyatakan bahwa Public Speaking merupakan bentuk komunikasi efektif melalui kemampuan menyampaikan ide, pendapat di depan umum. Akan tetapi, fakta yang ditemukan pada EF Report (2018) menyatakan bahwa Indonesia masih rendah dalam kecakapan berbahasa Inggris. Indonesia masih menempati peringkat 39 dibandingkan dengan negara negara Asia lainnya. Menurut Trant (2018) dalam riset $\mathrm{EF}$ tersebut ditemukan bahwa negara yang masih rendah kecakapan Bahasa Ingrris menunjukkan bahwa negara tersebut belum siap menjadi warga dunia, masih dalam tahap mengkonsumsi belum pada tahap negosiasi, mediasi atau melobi bahkan berkompetisi. Riset ini mengindikasi bahwa kemampuan public speaking dalam bahasa Inggris pada era globalisasi menuntut peran pemerintah dan institusi pendidikan untuk menyiapkan generasi mudanya agar mampu beradaptasi dengan perubahan global, terutama dalam kemampuan berkomunikasi dalam Bahasa Inggris

Akan tetapi dalam proses membumikan Bahasa Inggris dalam kehidupan sehari-hari di kalangan masyarakat Indonesia mendapatkan beberapa tantangan. Pertama, Indonesia memiliki banyak suku sehingga menyebabkan banyaknya bahasa daerah. Di satu sisi, hal ini menjadi kekayaan sumber daya manusia Indonesia, tetapi di sisi lain menjadi tantangan dalam membuka pola pikir masyarakat untuk membiasakan Bahasa Inggris dalam kehidupan sehari hari tanpa menghilangkan identitas bangsa. Kedua, kebijakan pemerintah Indonesia menempatkan Bahasa Inggris sebagai "foreign language". Kebijakan ini menjadikan Bahasa Inggris sebagai bahasa yang perlu dipelajari dalam kurikulum tetapi sifatnya bukan sebagai praktik kehidupan sehari-hari dalam masyarakatnya. Kebijakan ini menjadikan Bahasa Inggris bukan menjadi Bahasa penghantar kedua dalam pembelajaran di kelas. Hasilnya, proses pembiasaan menjadi lebih sulit dibandingkan dengan negara-negara yang menggunakan bahasa Inggris sebagai "second language". Ketiga, tingkat kepercayaan diri masyarakat Indonesia khususnya generasi muda dalam berbahasa Inggris masih rendah.

Fenomena yang sama terjadi di pesantren Al-Ghozali. Sebagain besar santri di pesantren tersebut merupakan generasi muda, berkisar usia 16 s.d 20 tahun. Pesantren ini beralamat di Jl. Permata No.19 Curug Kecamatan Gunungsindur, Kabupaten Bogor, Jawa Barat. Mayoritas santri berasal dari 
Jakarta, Bogor, Tangerang, Banten, bahkan beberapa ada yang berasal dari luar pulau Jawa.Visi pesantren ini bertujuan mencetak generasi muslim yang handal dan siap memasuki era global. Untuk mewujudkan visinya, pesantren mengusung program pendidikan formal dan informal dalam bidang tahfidzul quran, tafsir quran dan hadis, dengan demikian santri bukan hanya menghapal tetapi juga memahami kandungan Alquran dan hadis. Program ini tidak hanya meliputi sampai level memahami tetapi juga menargetkan santri untuk mampu menyampaikan isi kandungan Alquran dan hadis tersebut kepada masyarakat, atau biasa disebut dakwah dengan tidak terbatas dalam bahasa Indonesia tapi juga bahasa Inggris. Tentunya kemampuan berbicara sangat diperlukan dalam berdakwah. Sebagaimana Khairiyah (2013) mengonfirmasi bahwa berbicara merupakan kemampuan puncak dalam berbahasa karena menjadi alat dalam menyampaikan maksud, tujuan, gagasan, isi pikiran dan hati seseorang kepada orang lainnya. Pendakwah memerlukan keterampilan mengolah dan menyusun kata menjadi kalimat indah yang bermakna, enak di dengar dan mampu mempengaruhi audience. Selain itu si pendakwah ketika berbicara didepan umum juga harus memiliki kemampuan terhindar dari persepsi yang salah atau membingungkan dari audience atas pikiran, ide, gagasan yang si pendakwah sampaikan. Dengan kata lain, semua orang mungkin mampu mengungkapkan ide/pikiran/gagasan kepada orang lain, tetapi belum tentu mampu merangkainya menjadi kalimat yang indah, tidak akan menimbulkan kontroversi/persepsi yang salah, wajar didengar dan dapat memengaruhi audiensnya.

Berdasarkan hasil survey Tim PkM UNPAM, masih terdapat ditemukan hambatan dalam mewujudkan visi misi pesantren terkait program dakwah tersebut. Tim PkM menemukan kemauan berbicara khususnya dalam Bahasa Inggris sudah ada, tetapi masih sebatas peracakapan biasa belum mengarah pada visi misi pesantren yaitu berdkawah atau berbicara di hadapan publik. Selain itu, ditemukan masalah kepercayaan diri siswa yang masih rendah ketika berbicara di depan umum. Banyak dari para siswa yang merasa khawatir dan takut melakukan kesalahan ketika berbicara di depan umum khususnya Bahasa Inggris, sehingga mereka lebih menjadi enggan untuk tampil berbicara di depan umum. Masalah lain adalah minimnya kebiasaan berbahasa Inggris dalam kehidupan sehari hari. Hal ini menyebabkan siswa merasa kosakata bahasa Inggris mereka masih rendah sehingga merasa takut untuk tampil di depan publik. Dari beberapa permasalahan yang ditemukan berdasarkan hasil survei dan observasi tersebut, maka realisasi pemecahan masalah yang harus diambil berfokus pada 2 hal yaitu bagaimana meningkatan kesadaran siswa untuk willing to communicate dan bagaimana meningkatan kepercayaan diri siswa tanpa merasa takut melakukan kesalahan berbicara di depan publik. Dengan demikian, tim PkM UNPAM memilih Public Speaking dalam bentuk Speech (pidato) sebagai solusi atas permasalahan yang ada di Pesantren Al-Ghozali tersebut.

\section{B. Pelaksanaan dan Metode}

Public speaking didefinisikan sebagai proses berkomunikasi dengan sekelompok besar audien. Ada beberapa jenis public speaking seperti pidato, story

ACITYA BHAKTI, Volume 2 Nomor 1, Februari 2022 


\section{Lida Holida Mahmud, Mursyid Anwar, Yamin \& Yunita}

telling, presentasi dan lain sebagainya. Dalam PkM ini, public speaking yaitu pidato dipilih sebagai solusi dari permasalahan yang dihadapi di pesantren Al-Ghozali. Pilihan ini juga merujuk pada visi dan misi mereka yaitu mencetak pendakwah handal dalam mensyiarkan isi AlQuran dan hadis kepada khalayak. Tujuan dilaksanakan PkM public speaking jenis pidato ini adalah untuk meningkatkan kepercayaan diri santri dalam berbicara di depan publik. Dalam bahasa Yunani, pidato disebut dengan retorika dan dalam bahasa Arab disebut Muhadhoroh (ceramah, kuliah atau dakwah). Menurut Webster's Third New International Dictionary dalam Aliyah (2020), public speaking adalah seni komunikasi lisan yang efektif dengan para pendengarnya dengan cara melibatkan ilmu pengetahuan. Contoh public Speaking yang rutin dilakukan orang Islam adalah pada khutbah/ceramah Jumat. Seseorang yang berpidato harus bisa menguasai, mengambil hati para audience agar pesan yang disampaikan mengenai sasaran yang tepat. Sementara itu, Lucas (2015) menyatakan public speaking merupakan cara menjadikan gagasan/pendapat seseorang menjadi pendapat publik dengan cara menyampaikannya kepada orang lain serta mempengaruhi orang lain tersebut. Lebih lanjut dia menjelaskan public speaking merupakan bentuk kekuatan masyarakat dalam mengekspresikan ide gagasan terkait isu-isu sosial yang berkembang sehingga memberikan peluang untuk perubahan pada segala sesuatu yang menjadi pusat perhatian si orator (orang yang melakukan public speaking). Alasan lain yang tidak kalah penting dari dipilihnya public speaking pidato sebagai solusi permasalahan di pesantren adalah karena seorang pendakwah harus memiliki kemampuan bukan hanya dalam orasi atau berbicara di depan umum, tetapi juga harus memiliki gestur atau bahasa tubuh yang baik dalam menyampaikan gagasan/pendapatnya di depan umum. Aisyah (2018) menyatakan bahwa public speaking khususnya pidato merupakan gabungan dari dua gaya komunikasi yaitu komunikasi verbal melalui orasi dan komunikasi non verbal melalui bahasa tubuh.

Adapun tahap pelaksanaan PkM public speaking pidato terdiri dari 3 tahap. Tahap pertama, tim PkM melakukan observasi dan survei permasalahan atau kendala yang dihadapi pengajar bahasa Inggris di Pesantren Al-Ghozali. Kegiatan ini dilaksanakan pada tanggal 10 Juni 2021. Tahap kedua adalah rangkaian kegiatan persiapan dan pembuatan video public speaking, seperti pada foto berikut:

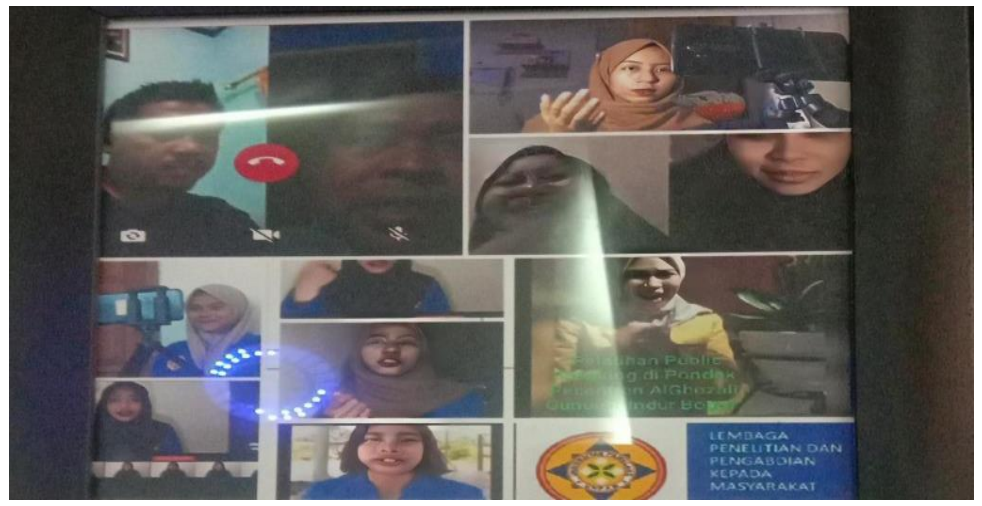

Gambar 1. Pembuatan video public speaking

ACITYA BHAKTI, Volume 2 Nomor 1, Februari 2022 
Gambar di atas merupakan gabungan foto persiapan dan foto pembuatan video. Bagian atas foto memperlihatkan rapat persiapann melalui Zoom meeting dimana dosen dan mahasiswa mendikusikan kegiatan PkM meliputi tema, teknik pembuatan video, alat yang dibutuhkan, pembiayaan dan strategi pelaksanaan PkM tatap muka. Kegiatan ini berlangsung tanggal 10 Juni 2021. Selanjutnya, foto bagian tengah ke bawah merupakan pelaksanaan pembuatan video public speaking yang dilakukan oleh mahasiswa UNPAM dengan dibimbing dosen PkM UNPAM. Pembuatan video tersebut dilaksanakan pada tanggal 11 s.d. 13 Juni 2021. Tahap ketiga merupakan pelatihan serta pengaplikasian video di Pesantren Al-Ghozali dengan pendampingan 3 dosen secara online dan 1 dosen PkM serta 2 mahasiswa secara offline serta dibantu oleh guru mentor pesantren. Hal ini dilakukan karena adanya aturan pembatasan jumlah orang yang masuk ke pesantren selama masa pandemi. Tahap ini dilaksanakan pada pada tanggal 20 Juli 2021 sebagaimana pada foto dibawah ini:

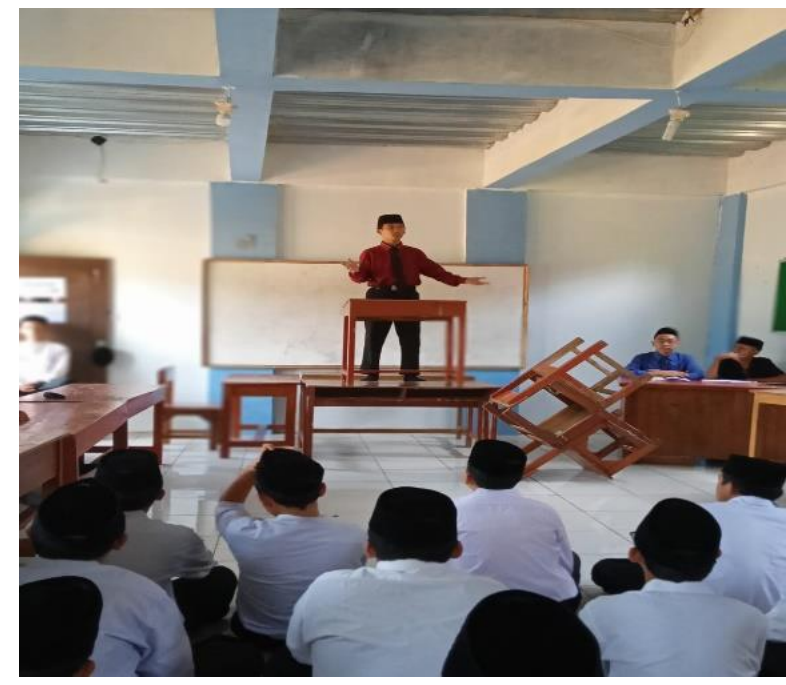

Gambar 2. Pelatihan video public speaking

Foto di atas merupakan kegiatan pelatihan public speaking secara offline dengan cara mengaplikasikan hasil video public speaking yang telah dibuat sebelumnya. Seperti diketahui bulan Juli merupakan puncak pandemi sehingga pesantren hanya mengijinkan 1 orang dosen dan 2 mahasiswa untuk langsung melatih siswanya. Dosen dan mahasiswa lainnya membimbing melalui partisipasi aplikasi Zoom. Terlihat pada foto, dosen Mursyid Anwar sedang memperhatikan dengan seksama praktek public speaking dalam bentuk pidato oleh seorang siswa. Selain itu, seorang guru pembimbing dari pesantren Al-Ghozali dan seorang mahasiswa sedang mengarahkan siswa yang sedang praktek

Metode pendekatan pada PkM public speaking di Pesantren Al-Ghozali adalah sebagai berikut: a) pendampingan melalui brainstorming untuk membuka cara pandang siswa terhadap pentingnya berbicara bahasa Inggris di depan umum. Selain itu, berbagi pengalaman yang menginspirasi dari kakak-kakak mahasiswa terkait upaya menanggulangi rasa malu dan takut ketika berbicara bahasa Inggris juga dilakukan pada tahap ini. Upaya tersebut dilakukan untuk mendorong kepercayaan 


\section{Lida Holida Mahmud, Mursyid Anwar, Yamin \& Yunita}

diri siswa. b) Pelatihan, pada tahap ini dilakukan pelatihan yang mengarah pada metode-metode pidato seperti impromptu, ektemporaneus, manuscript dan memorize sebagaimana yang ada pada video yang ditampilkan, serta tips dan triks berbicara lancar dalam public speaking pidato berbahasa Inggris, seperti bagaimana mengatasi rasa takut, malu dan sebagainya. c) Praktik, siswa melakukan praktik langsung berpidato bahasa Inggris untuk melihat sejauh mana proses pendampingan dan pelatihan berpengaruh pada motivasi mereka berbicara d) Pidato spontan, dilaksanakan dengan cara menunjuk santri secara acak untuk menyampaikan pidato secara spontan atau bisa mengambil tema dari judul pidato yang sudah disampaikan oleh peserta lain.

\section{Hasil dan Pembahasan}

Dari data hasil pengamatan dosen dan mahasiswa serta wawancara santri dan guru pembimbing menunjukan bahwa santri sangat antusias dalam mengikuti pelatihan public speaking. Sebelum pelatihan, hampir semua santri enggan maju ke depan dan saling tunjuk, khususnya ketika mereka diminta untuk secara sukarela maju ke podium berbicara bahasa Inggris dengan tema tema terkait isu isu sosial yang bisa mereka pilih. Dari hasil wawancara tersebut, terungkap banyak di antara mereka yang merasa demam panggung, tidak mau maju ke depan untuk bicara dikarenakan takut salah berbicara atau takut gugup di panggung. Disamping itu, mereka merasa tidak enak akan ditertawakan ketika dilihat oleh orang banyak. Keengganan mereka untuk maju tampil berbicara di depan umum ini selaras dengan teori Willingness to Communicate yang menyatakan bahwa semakin besar anxiety atau kekhawatiran maka semakin kecil keinginan untuk berkomunikasi (Mclyntre, et al, 1998). Setelah para santri diberikan pelatihan oleh dosen PKM dan mahasiswa barulah mereka mulai semangat untuk maju ke depan. Poin-point pelatihan meliputi: 1) apa itu public Speaking, 2) kenapa sebagai santri harus menguasai public speaking bahasa Inggris 3) Jenis jenis public Speaking salah satunya pidato , 4) cara menjadi Public Speaker yang baik dan percaya diri dan 5) kendala atau hambatan yang dihadapi santri dalam public speaking termasuk didalamnya trik dan tips menghilangkan rasa takut, malu dan gugup.. Pelatihan dilakukan bukan hanya menjelaskan tetapi juga diselipi permainan dan humor baik dari dosen maupun mahasiswa sehingga suasana yang tadinya menengangkan menjadi menyenangkan bagi santri. Hasilnya, pelaksanaan PkM bisa berjalan dengan baik dan para santri merasa lebih nyaman serta di antaranya banyak termotivasi untuk berani tampil berbicara di depan kelas. Hal ini seiring pernyataan Gardner (2001, pp. 1-19) bahwa motivasi secara bertahap memberi pengaruh pada kemauan belajar baik itu dengan cara menyukai sesuatu yang mengarah pada peningkatan kemauan belajar ataupun mengurangi kecemasan. Lebih lanjut, McCrosky dan Richmond (1992) menuturkan bahwa berbicara merupakan bentuk kemauan dalam berkomunikasi yang prosesnya terjadi ketika kenyamanan terbentuk pada diri si pembelajar. Hal yang sama terlihat pada santri. Setelah pelatihan public speaking, santri menjadi semangat praktik langsung berpidato bahasa Inggris,

ACITYA BHAKTI, Volume 2 Nomor 1, Februari 2022 
walaupun masih ada di antaranya ketika tampil terbata bata bahkan hampir terdiam beberapa detik seperti sedang berpikir karena lupa dengan kosakata yang akan diucapkan, padahal sebelumnya mereka telah menyiapkan konsep. Dari hasil wawancara dengan santri yang mengalami hal tersebut, mereka menyatakan bahwa pelatihan public speaking ini sangat menyenangkan sehingga mereka bisa lebih rileks tanpa merasa takut atau gugup ketika tampil. Akan tetapi keterbatasan kosakata terhadap tema yang diberikan membuat mereka akhirnya mengalami jeda terdiam di depan forum. Temuan ini menunjukkan bahwa kemampuan public speaking tidaklah secara langsung karena ada proses pembiasaan dan penguasaan kosakata sebelum masuk ke tahap public speaking. Keraf dalam Kuncoro (2017) menyatakan bahwa kosakata merupakan alat penyalur ide dan gagasan, sehingga semakin banyak kosakata yang dikuasai semakin banyak dan lancar gagasan tersampaikan. Temuan ini membuktikan bahwa diperlukan kegiatan-kegiatan serupa untuk peningkatan kompetensi kosakata bahasa Inggris santri AL-Ghozali. Dari kegiatan PkM tersebut, ditemukan pula beberapa santri yang tidak mengerti tema yang diberikan. Padahal tema dalam public speaking pada umumnya merupakan isu-isu hangat dalam masyarakat. Ketidakmengertian mereka terhadap tema menandakan bahwa santri kurang mendapat paparan informasi sehingga kurang mapan dalam mengkritisi dan menyikapi kondisi yang sedang terjadi di masyarakat. Temuan tersebut mengindikasikan bahwa kegiatan yang menunjang public speaking khususnya kegiatan yang mengasah kekritisan berpikir harus lebih sering dilaksanakan di pesantren, contohnya debating ataupun bedah buku.

\section{Penutup}

\section{Simpulan}

Pelatihan public speaking pidato melalui pembinaan online dan tatap muka telah berjalan baik, menyenangkan dan mendapat respon positif yang ditandai dengan antusiasme santri. Adanya antusiasme siswa yang tadinya enggan maju menjadi mau tampil berbicara ke depan umum setelah mendapat pelatihan public speaking tentang jenis metode pidato serta trik dan tips berbicara tanpa rasa takut meskipun masih ada santri yang masih terlihat malu-malu. Hal ini mengindikasikan bahwa: a) pelatihan public speaking menumbuhkan motivasi dalam mengembangkan bakat calon public speaker yang handal di lingkungan Pesantren AlGhozali. b) Pelatihan dan pembelajaran public speaking memberikan harapan dalam pembentukan karakter dan penanaman nilai-nilai positif pada santri sebagai calon pendakwah yang berkarakter dan prospektif. c) Pelatihan dan pembelajaran public speaking dapat menjadi upaya dalam meningkatkan kemampuan dasar berbahasa Inggris khususnya keterampilan berbicara. d) Pelatihan dan pembelajaran public speaking dapat menjadi upaya dalam meningkatkan kepercayaan diri siswa untuk tampil didepan publik baik dalam bahasa Indonesia ataupun bahasa Inggris. e) Pelatihan public speaking dalam rangka memperbaiki kemampuan berbahasa dan teknik berpidato dapat menjadi kegiatan yang menyenangkan jika mereka diberikan berbagai aktivitas yang bervariasi.

ACITYA BHAKTI, Volume 2, Nomor 1, Februari 2022 


\section{Saran}

Lomba public speaking seperti pidato, storry telling dan presentasi dalam berbahasa Inggris dapat dilakukan tiap tahun untuk meningkatkan kemampuan santri dalam public speaking sehingga bisa menjadi alat mewujudkan visi pesantren dalam membentuk generasi muslim sebagai pendakwah yang berkarakter. Akan tetapi, hal ini hanya bisa terwujud apabila dilakukan secara berkesinambungan menjadi sebuah pembiasaan serta ditunjang oleh kegiatan kegiatan lainnya yang mampu memupuk kepercayaan diri santri berbahasa Inggris tidak hanya bersifat konsumtif tetapi juga negosiatif. Pondok Pesantren Al-Ghozali harus lebih bersinergi dan bekerjasama dengan pihak-pihak yang bertujuan mencerdaskan dan memajukan keterampilan public speaking para santri.

\section{Ucapan Terima Kasih}

Terima kasih kepada pihak LPPM UNPAM dan Pesantren Al-Ghozali yang telah memfasilitasi kegiatan PkM Public Speaking ini.

\section{DAFTAR PUSTAKA}

Aliyah, F. (2020). Pengaruh kegiatan ekstrakurikuler public speaking terhadap karakter komunikatif peserta didik kelas IV-VI Madrasah Ibtidaiyah Darul Fikri Bringin Kauman Ponorogo tahun pelajaran 2019/2020 (Doctoral dissertation, Universitas Muhammadiyah Ponorogo).

Asiyah, S. (2018). Implementasi komunikasi verbal dan nonverbal dalam kegiatan public speaking santri di pondok pesantren Darul Falah Amtsilati Putri Bangsri Jepara (Doctoral dissertation, UIN Walisongo).

Gardner, R. C. (2001). Integrative motivation and second language acquisition. Motivation and second language acquisition, 23(1), 1-19.

Girsang, L. R. M. (2018). 'Public speaking sebagai bagian dari komunikasi efektif (kegiatan PKM di SMA Kristoforus 2, Jakarta Barat) Jurnal Pengabdian dan Kewirausahaan, 2(2), 81-85.

Khayyirah, B. (2013). Cara pintar berbicara cerdas di depan public, Diva Press

Kuncoro, A. (2017). Korelasi penguasaan kosakata dengan keterampilan berbicara siswa dalam bahasa Inggris. SAP (Susunan Artikel Pendidikan), 1(3).

Lucas, S. E. (2012). The art of public speaking. $12^{\text {th }}$ edition. McGrow-Hill Companies.

MacIntyre, P. D., Clément, R., Dörnyei, Z., \& Noels, K. A. (1998). Conceptualize in willingness to communicate in a L2: A situational model of L2 confidence and affiliation. The Modern Language Journal, 82(4), 545-562.

McCroskey, J. C. (1992). Reliability and validity of the willingness to communicate scale.Communication Quarterly, 40(1), 16-25.

Rahayu, E. M. (2018). Nilai kecakapan bahasa Inggris Indonesia di bawah rata-rata Asia. $\quad$ https://kumparan.com/swaonline/nilai-kecakapan-bahasa-inggrisindonesia-di-bawah-rata-rata-asia-1544773491925403465 